\title{
Ambang Pendengaran Rerata pada Sopir Mikrolet Trayek Teling - Pusat Kota Manado
}

\author{
Indah Montolalu, ${ }^{1}$ Steward K. Mengko. ${ }^{2}$ Joshua Runtuwene ${ }^{2}$
}

\author{
${ }^{1}$ Program Studi Pendidikan Dokter Fakultas Kedokteran Universitas Sam Ratulangi Manado \\ ${ }^{2}$ Bagian/SMF Telinga Hidung Tenggorok Kepala Leher Fakultas Kedokteran Universitas \\ Sam Ratulangi Manado \\ Email: montolalu_indah@yahoo.com
}

\begin{abstract}
Normal hearing has to be maintained by applying healthy life style, avoiding noise, as well as early detecting of hearing disorders. This study was aimed to obtain the average hearing thresholds of microbus drivers for public transportation in Manado, more specifically of Teling-downtown route. This was an observational and descriptive study with a crosssectional design. Respondents were 66 microbus drivers; all were male. Data were obtained by performing audio-level test and ear examination on the respondents. The results showed that, of the right ear, 27 respondents had normal hearing; 32 respondents had mild hearing loss; and 7 respondents had moderate hearing loss. Of the left ear, 21 respondents had normal hearing; 39 respondents had mild hearing loss; and 6 respondents had moderate hearing loss. In conclusion, most of the microbus drivers had mild hearing loss.
\end{abstract}

Keywords: hearing threshold, microbus driver.

\begin{abstract}
Abstrak: Kesehatan pendengaran perlu diperlihara dengan menerapkan pola hidup bersih dan sehat, menghindari pendengaran dari kebisingan, serta melakukan pemeriksaan atau deteksi dini terhadap adanya gangguan pendengaran. Penelitian ini bertujuan untuk memperoleh ambang pendengaran rerata pada sopir mikrolet trayek Teling - Pusat Kota Manado. Jenis penelitian ialah deskriptif observasional dengan desain potong lintang. Responden penelitian sebanyak 66 orang sopir mikrolet; semuanya berjenis kelamin laki-laki. Data penelitian diperoleh dengan melakukan pemeriksaan ambang pendengaran menggunakan audiometer serta pemeriksaan fisik telinga pada sopir mikrolet Trayek Teling-Pusat Kota Manado yang menjadi responden penelitian. Hasil penelitian mendapatkan derajat pendengaran pada telinga kanan sebagai berikut: pendengaran normal pada 27 responden; penurunan derajat ringan pada 32 responden; dan penurunan derajat sedang pada 7 responden. Untuk telinga kiri, yakni pendengaran normal pada 21 responden; penurunan derajat ringan pada 39 responden; dan penurunan derajat sedang pada 6 responden. Simpulan penelitian ini ialah sebagian besar sopir mikrolet trayek Teling-Pusat Kota Manado mengalami penurunan pendengaran derajat ringan.

Kata kunci: ambang pendengaran, sopir mikrolet
\end{abstract}

\section{PENDAHULUAN}

Gangguan pendengaran yaitu berkurangnya kemampuan pendengaran baik sebagian atau seluruhnya, pada salah satu atau kedua telinga, baik derajat ringan atau lebih berat dengan ambang pendengaran lebih dari $25 \mathrm{~dB}$ pada frekuensi 500, 1000, 2000 dan $4000 \mathrm{~Hz}$. Terdapat tiga jenis gangguan pendengaran yang dapat diketa- hui dengan melakukan uji pendengaran yaitu gangguan sensorineural, gangguan konduktif, dan gabungan dari keduanya atau gangguan tipe campuran. ${ }^{1}$

Data Riset Kesehatan Dasar (Riskesdas) Kementerian Kesehatan Republik Indonesia pada tahun 2013, menunjukkan bahwa $2,6 \%$ penduduk Indonesia berusia 5 tahun ke atas mengalami gangguan pende- 
ngaran, 0,09\% mengalami ketulian, $18,8 \%$ terdapat sumbatan serumen, dan $2,4 \%$ terdapat sekret di liang telinga. ${ }^{2}$ Banyak kasus gangguan pendengaran menunjukan akibat pajanan kebisingan yang lama, akan tetapi pada beberapa kasus bukan karena masalah pekerjaan.

Angkutan kota merupakan angkutan umum dari suatu tempat ke tempat yang lain di dalam wilayah kota dengan menggunakan mobil bus atau mobil penumpang umum yang termasuk dalam trayek tetap dan teratur. ${ }^{4}$ Angkutan kota yang berada di daerah Manado merupakan salah satu jenis angkutan yang tergolong unik dibandingkan di tempat lain karena sering dilengkapi dengan perangkat musik yang lengkap dan digunakan dengan volume keras. Begitu juga dengan angkutan umum pada mikrolet trayek Teling-Pusat Kota Manado, yang dilengkapi dengan peralatan sound system.

Jalur Teling-Pusat Kota Manado ialah jalur yang terbising pada jam sibuk yakni jam sekolah dan jam kerja. Biasanya sopir mikrolet memasang sound system untuk menarik perhatian dan mendapatkan penumpang. Hal ini mungkin dapat menyebabkan gangguan pendengaran pada sopir mikrolet dan penumpang akibat penggunaan volume sound system yang keras.

Saat ini, belum terdapat penelitian yang jelas tentang ambang pendengaran rerata pada sopir mikrolet trayek TelingPusat Kota Manado. Berdasarkan masalah di atas, maka peneliti merasa tertarik untuk mengetahui ambang pendengaran rerata pada sopir mikrolet trayek Teling-Pusat Kota Manado.

\section{METODE PENELITIAN}

Penelitian ini dilaksanakan di Puskesmas Teling Atas Kota Manado selama 3 minggu pada setiap hari Kamis. Jenis penelitian ialah desktriptif observasional dengan desain potong lintang. Responden penelitian ialah sopir mikrolet trayek TelingPusat Kota Manado yang diperoleh dengan teknik total sampling. Pengambilan data dilakukan dengan pemeriksaan audiometri oleh dokter spesialis bagian THT-KL. Data diolah dengan menggunakan Microsoft
Excell 2013 kemudian disajikan dalam bentuk tabel.

Penelitian ini telah mendapat persetujuan dari Komisi Etik Penelitian Kesehatan RSUP Prof. Dr. R. D. Kandou Manado, dengan nomor keterangan layak etik yaitu No. 081/EC/KEPK-KANDOU/XI/2019.

\section{HASIL PENELITIAN}

Hasil penelitian ini mendapatkan sebanyak 66 orang sopir mikrolet trayek TelingPusat Kota Manado dengan jenis kelamin laki-laki sebagai responden penelitian.

Tabel 1 memperlihatkan persentasi usia tertinggi ialah usia 16-25 tahun yaitu 17 orang (26\%), dan yang terendah ialah usia 66-75 tahun yaitu 3 orang (4\%).

Tabel 1. Distribusi berdasarkan usia responden

\begin{tabular}{ccc}
\hline $\begin{array}{c}\text { Usia } \\
\text { tahun) }\end{array}$ & $\mathbf{N}$ & $\begin{array}{c}\text { Persentase } \\
(\%)\end{array}$ \\
\hline $16-25$ & 17 & $26 \%$ \\
$26-35$ & 6 & $9 \%$ \\
$36-45$ & 15 & $23 \%$ \\
$46-55$ & 13 & $20 \%$ \\
$56-65$ & 12 & $18 \%$ \\
$66-75$ & 3 & $4 \%$ \\
Total & 66 & $100 \%$ \\
\hline
\end{tabular}

Tabel 2 memperlihatkan bahwa responden yang terbanyak ialah lama bekerja $>10$ tahun yaitu 42 orang (64\%) dibandingkan dengan lama kerja 1-10 tahun sebanyak 24 orang (36\%).

Tabel 2. Distribusi berdasarkan lama bekerja responden (tahun)

\begin{tabular}{ccc}
\hline $\begin{array}{c}\text { Lama bekerja } \\
\text { (tahun) }\end{array}$ & N & $\begin{array}{c}\text { Persentase } \\
(\%)\end{array}$ \\
\hline$>10$ & 42 & $64 \%$ \\
$1-10$ & 24 & $36 \%$ \\
Total & 66 & $100 \%$ \\
\hline
\end{tabular}

Tabel 3 memperlihatkan bahwa responden terbanyak yaitu 61 orang (92\%) bekerja 7-12 jam sehari sedangkan 5 orang lainnya (8\%) bekerja 13-18 jam sehari.

Tabel 4 memperlihatkan bahwa responden terbanyak yaitu 41 orang $(62 \%)$ bekerja selama 6 hari dalam seminggu 
sedangkan 25 orang lainnya $(38 \%)$ bekerja 7 hari dalam seminggu.

Tabel 5 memperlihatkan bahwa responden terbanyak dengan keadaan normal meatus acusticus externa (MAE) pada telinga kanan dan kiri yaitu 61 orang (92\%), sedangkan pada 5 orang $(8 \%)$ terdapat serumen minimal pada telinga kanan dan kiri.

Tabel 6 memperlihatkan seluruh responden $(100 \%)$ memiliki membran timpani normal pada telinga kanan dan kiri.

Tabel 7 memperlihatkan hasil pemeriksaan audiometri yaitu responden terbanyak dengan penurunan pendengaran derajat ringan (48\% telinga kanan dan 59\% telinga kiri) disusul oleh derajat pendengaran normal.
Tabel 3. Distribusi berdasarkan lama bekerja responden dalam durasi jam (sehari)

\begin{tabular}{ccc}
\hline $\begin{array}{c}\text { Lama bekerja } \\
\text { sehari (jam) }\end{array}$ & $\mathbf{N}$ & $\begin{array}{c}\text { Persentase } \\
(\boldsymbol{\%})\end{array}$ \\
\hline 7 - 12 Jam & 61 & $92 \%$ \\
13 - 18 Jam & 5 & $8 \%$ \\
1 - 6 Jam & 0 & $0 \%$ \\
19 -24 Jam & 0 & $0 \%$ \\
Total & 66 & $100 \%$ \\
\hline
\end{tabular}

Tabel 4. Distribusi berdasarkan lama bekerja (hari) responden dalam seminggu

\begin{tabular}{ccc}
\hline $\begin{array}{c}\text { Semingu } \\
\text { (hari kerja) }\end{array}$ & N & $\begin{array}{c}\text { Persentase } \\
(\boldsymbol{\%})\end{array}$ \\
\hline 6 hari & 41 & $62 \%$ \\
7 hari & 25 & $38 \%$ \\
Total & 66 & $100 \%$ \\
\hline
\end{tabular}

Tabel 5. Distribusi berdasarkan kondisi fisik telinga untuk MAE pada responden

\begin{tabular}{ccccc}
\hline $\begin{array}{c}\text { Meatus acusticus } \\
\text { externus }\end{array}$ & Kanan & Kiri & Kanan & Kiri \\
\hline Normal & 61 & 61 & $92 \%$ & $92 \%$ \\
Serumen minimal & 5 & 5 & $8 \%$ & $8 \%$ \\
Total & 66 & 66 & $100 \%$ & $100 \%$ \\
\hline
\end{tabular}

Tabel 6. Distribusi berdasarkan kondisi membran timpani pada responden

\begin{tabular}{ccccc}
\hline Membran timpani & \multicolumn{2}{c}{$\mathbf{N}$} & \multicolumn{2}{c}{ Persentase (\%) } \\
& Kanan & Kiri & Kanan & Kiri \\
\hline Normal & 66 & 66 & $100 \%$ & $100 \%$ \\
Perforasi & 0 & 0 & $0 \%$ & $0 \%$ \\
Sikatriks & 0 & 0 & $0 \%$ & $0 \%$ \\
Total & 66 & 66 & $100 \%$ & $100 \%$ \\
\hline
\end{tabular}

Tabel 7. Distribusi derjat pendengaran berdasarkan hasil pemeriksaan audiometri pada responden

\begin{tabular}{cccccc}
\hline \multicolumn{2}{c}{ Derajat pendengaran } & \multicolumn{2}{c}{$\mathbf{N}$} & \multicolumn{2}{c}{ Persentase (\%) } \\
& & Kanan & Kiri & Kanan & Kiri \\
\hline $0-25 \mathrm{~dB}$ & Normal & 27 & 21 & $41 \%$ & $32 \%$ \\
$>25-40 \mathrm{~dB}$ & Tuli ringan & 32 & 39 & $48 \%$ & $59 \%$ \\
$>40-55 \mathrm{~dB}$ & Tuli sedang & 7 & 6 & $11 \%$ & $9 \%$ \\
$>55-70 \mathrm{~dB}$ & Tuli sedang - berat & 0 & 0 & $0 \%$ & $0 \%$ \\
$>70-90 \mathrm{~dB}$ & Tuli berat & 0 & 0 & $0 \%$ & $0 \%$ \\
$>90 \mathrm{~dB}$ & Tuli sangat berat & 0 & 0 & $0 \%$ & $0 \%$ \\
Total & & 66 & 66 & $100 \%$ & $100 \%$ \\
\hline
\end{tabular}




\section{BAHASAN}

Pada penelitian ini, sopir mikrolet trayek Teling-Pusat Kota Manado yang bersedia mengikuti penelitian sekaligus dilakukan pemeriksaan sebanyak 66 dari 91 responden. Terdapat 21 responden yang dieksklusikan, yaitu: riwayat trauma kepala sebanyak 12 responden, riwayat keluar cairan sebanyak 8 responden; riwayat gangguan pendengaran sebanyak 6 responden; serumen obturans pada telinga kanan dan kiri sebanyak 1 responden; serumen total pada telinga kanan dan kiri sebanyak 6 responden; perforasi pada telinga kanan dan kiri sebanyak 1 responden; otitis media akut 1 responden; otitis media supuratif kronik 2 responden; dan sulit diidentifikasi pada telinga kanan dan kiri sebanyak 7 responden. Semua responden penelitian berjenis kelamin laki-laki.

Kemungkinan penyebab gangguan pendengaran akibat kebisingan biasanya berupa tuli sensorineural, sehingga kemungkinan lain perlu disingkirkan. Adanya perforasi, otitis media, serumen obsturan, serumen total menunjuk ke arah tuli konduksi.

Gangguan pendengaran merupakan suatu keadaan dimana seseorang tidak bisa mendengarkan suara pada satu atau kedua telinga baik secara parsial maupun total. ${ }^{5}$ Secara umum gangguan pendengaran dibagi atas beberapa tipe, yakni tipe konduktif, sensorineural, dan tipe campuran atau gabungan dari kedua tipe tersebut. ${ }^{6}$ Tuli konduktif terjadi bila terdapat adanya gangguan dalam hantaran bunyi sistem konduksi di dalam telinga, sedangkan tuli sensorineural terjadi bila seseorang mengalami gangguan pada fungsi sistem sensoris serta saraf pendengaran, misalnya akibat adanya kerusakan pada sel-sel rambut di dalam koklea, nervus VIII, dan pusat pendengaran yakni dibagian korteks serebri. Tipe campuran terjadi bila terdapat gangguan dalam penghantaran bunyi sistem konduksi di dalam telinga tengah dan adanya gangguan dalam sistem saraf pendengaran. ${ }^{6}$

Responden penelitian ini yang terbanyak berusia 16-25 tahun yaitu 17 orang
(26\%), diikuti secara berturut usia 36-45 tahun (23\%), usia 46-55 tahun (20\%), usia 56-65 tahun (18\%), usia 26-35 tahun (9\%), dan usia 66-75 tahun (4\%).

Berdasarkan lama kerja responden, yang terbanyak ialah lama bekerja $>10$ tahun yaitu 24 orang dibandingkan dengan lama kerja 1-10 tahun yaitu 42 orang. Berdasarkan lama bekerja dalam durasi jam untuk sehari diperoleh 61 orang bekerja 712 jam sehari sedangkan 5 orang lainnya bekerja 13-18 jam sehari. Berdasarkan lama bekerja dalam seminggu terdapat 41 orang bekerja selama 6 hari sedangkan 25 orang lainnya bekerja 7 hari dalam seminggu. Menurut acuan pustaka, individu dengan masa kerja di atas 10 tahun dan intensitas kebisingan lebih dari $85 \mathrm{~dB}$ lebih rentan mengalami gangguan pendengaran. ${ }^{7}$

Pada penelitian ini dilakukan pemeriksaan kondisi fisik telinga pada responden. Sebagian besar responden (92\%) memiliki kondisi MAE normal (92\%); serumen minimal pada telinga kanan dan kiri sebanyak 5 orang (8\%); serta membran timpani normal pada telinga kanan dan kiri sebanyak 66 orang (100\%). Serumen merupakan hasil dari produksi kelenjar sebasea, kelenjar seruminosa, epitel kulit yang terlepas, dan partikel debu. ${ }^{8}$ Serumen yang telah mengakibatkan terjadi sumbatan (serumen obturans) dapat menimbulkan adanya gejala klinik selain gangguan pendengaran yaitu adanya rasa nyeri bila serumen yang keras menekan dinding liang telinga, telinga yang berdengung (tinnitus), dan vertigo bisa terjadi bila serumen obturans menekan membran timpani. ${ }^{9}$

Pada pemeriksaan audiometri terhadap responden didapatkan bahwa untuk telinga kanan ambang pendengaran berdasarkan klasifikasi ISO yakni derajat normal sebanyak 27 orang (41\%), penurunan derajat ringan sebanyak 32 orang $(48 \%)$, dan penurunan derajat sedang 7 orang $(11 \%)$. Untuk telinga kiri yakni derajat normal sebanyak 21 orang (41\%), penurunan derajat ringan sebanyak 39 orang (59\%), dan penurunan derajat sedang 6 orang $(9 \%)$. Penelitian oleh Manoppo et al ${ }^{10}$ terhadap petugas PT. Gapura angkasa di 
Bandar Udara Sam Ratulangi Manado unutk mengetahui adanya gangguan pendengaran akibat kebisingan di lingkungan kerja, mendapatkan hasil pemeriksaan pendengaran dengan menggunakan audiometri nada murni sebanyak 4 orang yang mengalami gangguan pendengaran pada kedua telinganya (20\%), 16 orang normal, sedangkan 1 orang walaupun pure tone average (PTA) dalam batas normal tetapi telah mengalami penurunan pada frekwensi $4000 \mathrm{~Hz}(80 \%)$.

Ambang pendengaran merupakan suara dengan frekuensi terendah yang masih bisa didengar seseorang, sehingga semakin rendah suara yang masih dapat didengar seseorang maka semakin rendah nilai ambang pendengaran (NAP), yang berarti semakin baik juga telinga seseorang. Pemeriksaan audiometeri nada murni merupakan suatu pemeriksaan yang rutin dilakukan agar dapat mendeteksi adanya gangguan dalam pendengaran. ${ }^{11}$

Derajat gangguan pendengaran dinilai dengan cara menghitung PTA yaitu intensitas pendengaran rerata pada frekuensi 500 $\mathrm{Hz}, 1.000 \mathrm{~Hz}$, dan $2.000 \mathrm{~Hz}$ dalam desiBell atau dB (ANSI-1969). Penilaian dilakukan pada masing-masing telinga dan telinga yang lebih baik digunakan untuk menentukan derajat pendengaran seseorang. ${ }^{6}$

Noise induced hearing loss (NIHL) dan presbikusis merupakan suatu gangguan pendengaran tipe sensorineural. Kurangnya pendengaran akibat bising di dalam lingkungan kerja terjadi akibat kebisingan sehingga memungkinkan terjadinya NIHL, terutama pada pekerja yang berada di lingkungan tempat kerja. ${ }^{6}$

Hasil penelitian yang dilakukan terhadap sopir mikrolet trayek Teling-Pusat Kota Manado mendapatkan hanya 5 responden (masing-masing untuk telinga kanan dan kiri) yang mengalami gangguan pada MAE sedangkan untuk membran timpani semua responden memiliki hasil normal. Namun pada pemeriksaan audiometri didapatkan yang mengalami penurunan derjat pendengaran lebih banyak dibandingkan dengan derajat pendengaran normal.

Peneliti mengalami keterbatasan dalam desain penelitian yaitu kurangnya penjelasan pada responden, serta waktu dan lokasi penelitian yang kurang memadai. Dalam penelitian ini juga tidak sempat dilakukan pemeriksaan fungsi pendengaran menggunakan garputala untuk hantaran tulang.

Hasil penelitian ini belum dapat dijadikan suatu tolak ukur untuk status kesehatan telinga untuk sopir mikrolet. Hal ini juga dikarenakan dari total responden yang awalnya sebanyak 91 orang namun dalam penelitian yang dilakukan, ternyata sebagian sopir mikrolet tidak dapat mengikuti penelitian ini sehingga hanya didapatkan 66 orang sopir sebagai responden penelitian.

\section{SIMPULAN}

Pada sebagian besar sopir mikrolet trayek Teling-Pusat Kota Manado didapatkan penurunan pendengaran derajat ringan.

Bagi sopir mikrolet yang memiliki masalah pada kesehatan telinga seperti adanya ganguan pendengaran agar melakukan konsultasi kepada dokter spesialis THTKL. Perlu dilakukan penelitian lanjut untuk mengetahui pengaruh paparan bising terhadap ambang pendengaran pada sopir mikrolet yang sering terpapar bising. Selain itu, perlu dilakukan penyuluhan kesehatan untuk meminimalkan risiko terjadinya gangguan pendengaran pada sopir mikrolet. Diharapkan hasil penelitian ini dapat dijadikan bahan perbandingan untuk usulan regulasi kebisingan di kendaraan umum oleh pemerintah.

\section{Ucapan Terima Kasih}

Ucapan terima kasih ditujukan kepada seluruh sopir mikrolet trayek Teling-Pusat Kota Manado atas partisipasi dan kerja samanya selama dilakukan penelitian hingga penyelesaian penelitian ini.

\section{Konflik Kepentingan}

Penulis menyatakan tidak terdapat konflik kepentingan dalam studi ini. 


\section{DAFTAR PUSTAKA}

1. Wuwung FR, Palandeng OI, Pelealu OC. Ambang pendengaran rata-rata pada penderita diabetes melitus di Poliklinik Endokrinologi RSUP Prof. Dr. R. D. Kandou Manado. e-CliniC. 2015;3(1): 26-32.

2. Kementerian Kesehatan Republik Indonesia. Telinga Sehat Investasi Masa Depan. Biro Komunikasi dan Pelayanan Masyarakat, Kementerian Kesehatan RI. [cited 2019 Aug 22]. Available from:http://www.depkes.go.id/pdf.php? $\mathrm{id}=18030500002$.

3. Apriluana G, Khairiyati L, Setyaningrum R. Hubungan antara usia, jenis kelamin, lama kerja, pengetahuan, sikap dan ketersediaan alat pelindung diri (APD) dengan perilaku penggunaan APD pada tenaga kesehatan. JPKMI. 2016;3(3): 82-7.

4. Istiqomah SN. Hubungan gangguan pendengaran dengan kualitas hidup lansia di panti sosial Tresna Werdha Natar tahun 2017. [cited 2019 Aug 22]. Available from:http://digilib.unila.ac.id/29908/

5. Martini E, Probandari A, Pratiwi D. Skrining dan edukasi gangguan pendengaran pada anak sekolah. IJMS. 2017;4(1): 110-7.

6. Dewi YA, Agustian RA. Skrining Gangguan dengar pada pekerja salah satu pabrik tekstil di Bandung. Majalah Kedokteran Bandung. 2012;44(2):96-100.

7. Tana L, Halim FS, Ghani L. Gangguan pendengaran akibat bising pada pekerja perusahaan baja di pulau Jawa. 2002. [cited 2019 Dec 2]. Available from: http://www.univmed.org/wpcontent/ uploads/2011/02/Dr._Lusi.pdf.

8. Hafil AF, Sosialisman H. Kelainan telinga luar. In: Soepardi EA, Iskandar N, Bashiruddin J, Restuti RD, editors. Buku Ajar Ilmu Penyakit THT (6th ed). Jakarta: Balai penerbit FKUI, 2007; p. 59-60.

9. Alriyanto CY. Pengaruh serumen obsturan terhadap gangguan pendengaran (Studi kasus pada siswa kelas V SD di Kota Semarang) [Disertasi]. [cited 2019 Dec 2]. Available from: http://eprints.undip. ac.id/23179/ 1/C._ Yuniardi.pdf.

10. Manoppo FN, Supit W, Danes VR. Hubungan antara kebisingan dan fungsi pendengaran pada petugas PT Gapura Angkasa di Bandar Udara Sam Ratulangi Manado. eBiomedik. 2014;2(1).

11. Limardjo A, Kadir A, Djamin R, Perkasa F. Analisis gangguan pendengaran pada penderita diabetes melitus tipe- 2 berdasarkan pemeriksaan audiometri nada murni dan audiometri tutur. YARSI Medical Journal. 2009;17(3): 192-203. 